\title{
Symbiotic drink based on Brazil nuts (Bertholletia excelsa H.B.K): production, characterization, probiotic viability and sensory acceptance
}

 Marcela de Alcantara ${ }^{3}\left[\right.$ Amauri Rosenthal $^{1,3}\left[\right.$ Elisa Helena da Rocha Ferreira ${ }^{1,4}[\mathbb{D}$}

${ }^{1}$ Programa de Pós-graduação em Ciência e Tecnologia de Alimentos (PPGCTA), Instituto de Tecnologia (IT), Universidade Federal Rural do Rio de Janeiro (UFRRJ), 23890-000, Seropédica, RJ, Brasil. E-mail: pc.cunha.alim@gmail.com. *Corresponding author.

${ }^{2}$ Graduação em Engenharia de Alimentos, Instituto de Tecnologia (IT), Universidade Federal Rural do Rio de Janeiro (UFRRJ), Seropédica, RJ, Brasil.

${ }^{3}$ Embrapa Agroindústria de Alimentos, Rio de Janeiro, RJ, Brasil.

${ }^{4}$ Departamento de Tecnologia de Alimentos (DTA), Instituto de Tecnologia (IT), Universidade Federal Rural do Rio de Janeiro (UFRRJ), Seropédica, RJ, Brasil.

ABSTRACT: Brazil nut is a typical oilseed from the Amazon region, of great economic and cultural importance. Due to its high nutritional value, it is interesting to be used as a matrix for new products' development. Thus, the present study aimed to develop and characterize a drink based on Brazil nuts fermented by Lactobacillus casei and added with inulin. After formulated, the drink was pasteurized, fermented, maturated, and stored under refrigeration for 28 days. Physical, chemical, microbiological, and sensory analyzes were performed before and after fermentation, at 7-day intervals. There was maintenance in the content of lipids and proteins and reduction in the concentrations of fibers, ash, total carbohydrates, and moisture. The fermented drink $\mathrm{pH}$ decreased significantly during storage, while the acidity and the soluble solids content increased from the 14th day. Regarding the color, there were significant changes in all parameters analyzed. In the fermented drink, the development of molds and yeasts, total and thermotolerant coliforms, and Salmonella were not verified, while the control drink deteriorated after 7 days. The probiotic L. casei had count ranging from 9.48 to $8.59 \log C F U m L^{-1}$ during the 28 days. When exposed to in vitro gastrointestinal conditions, L. casei significantly reduced its concentration. However, it reached the enteric phase with counts greater than 6.00 $\log U F C \mathrm{~mL}^{-1}$. Sensorially, the drink reached intermediate scores (between 5.41 and 6.02). Therefore, the use of Brazil nuts proved to be viable for the development of a product free of animal-origin components, symbiotic, and of outstanding nutritional quality. Key words: Lactobacillus casei, functional drink, fermented "vegetable milk", probiotics.

Bebida simbiótica à base de castanha-do-Brasil (Bertholletia excelsa H.B.K): produção, caracterização, viabilidade probiótica e aceitação sensorial

RESUMO: A castanha-do-Brasil é uma oleaginosa típica da região Amazônica, de grande importância econômica e cultural. Devido ao seu alto valor nutritivo, torna-se interessante a sua utilização como matriz para o desenvolvimento de novos produtos. Assim, o presente estudo teve como objetivo o desenvolvimento e caracterização de uma bebida à base de castanha-do-Brasil fermentada por Lactobacillus casei e adicionada de inulina. Após formulada, a bebida foi pasteurizada, fermentada, maturada e armazenada sob refrigeração por 28 dias. Foram realizadas análises físicas, químicas, microbiológicas e sensoriais antes e após a fermentação, em intervalos de sete dias. Observou-se uma manutenção no teor de lipídeos e proteinas e redução nas concentrações de fibras, cinzas, carboidratos totais e umidade. O pH da bebida fermentada reduziu significativamente ao longo do armazenamento, enquanto a acidez e o teor de sólidos solúveis aumentaram a partir do $14^{\circ}$ dia. Em relação à cor, houve alterações significativas em todos os parâmetros analisados. Na bebida fermentada, não foi verificado o desenvolvimento de bolores e leveduras, coliformes totais e termotolerantes e Salmonella, enquanto a bebida controle se deteriorou após sete dias. O probiótico L. casei apresentou contagens variando de 9.48 a $8.59 \log C F U \mathrm{~mL}^{-1}$ durante os 28 dias de armazenamento. Quando exposto às condições gastrointestinais in vitro, o L. casei diminui a sua concentração significativamente. Contudo, atingiu a fase entérica com contagens superiores a $6.00 \log U F C \mathrm{~mL}^{-1}$. Sensorialmente, a bebida alcançou scores intermediários (entre 5.41 e 6.02). Dessa forma, a utilização da castanha-do-Brasil se mostrou viável para o desenvolvimento de um produto isento de componentes de origem animal, simbiótico e de destacável qualidade nutricional.

Palavras-chave: Lactobacillus casei, bebida funcional, "leite vegetal” fermentado, probióticos.

\section{INTRODUCTION}

Consumer interests in new healthy eating habits have strongly boosted the functional food market, highlighting the increased intake of products presenting bioactive characteristics. These products (industrially processed or not), when eaten regularly, in adequate amounts and on a balanced and diverse 
diet, provide a better quality of life and well-being, leading to physical and mental health benefits, in addition to supplying nutritional needs (GRANATO et al., 2017; KÜSTER-BOLUDA \& VIDALCAPILLA, 2017). However, food functionality claim is conditioned to the proof of its toxicological safety and benefits effectiveness when ingested, through adequate clinical trials and experimental scientific evidence (ASSMANN et al. 2014, GRANATO et al., 2020).

Among the functional foods available worldwide, some contain probiotics and prebiotics, which can be ingested either in isolation or in combination. Commonly, probiotics are defined as living microorganisms that, when ingested at adequate levels, confer some benefit to the host health (HILL et al., 2014). Although, this definition is widely used by the scientific community, recent studies indicate that dead, inactivated and/or disrupted cells, as well as cellular extracts and metabolites, can bring some benefit to human health. ZENDEBOODI and collaborators (2020) proposed an updated definition, which covers all these aspects. Therefore, probiotics are microbial cells (viable or not) potentially beneficial to the host's health. Distinctively, prebiotics is defined as components selectively metabolized by microorganisms, providing health benefits to the host (GIBSON et al., 2017). The combined use of probiotics and prebiotics can be defined as symbiotic, consisting of the mutual exploitation of their benefits (VIRK et al., 2013).

Nowadays, the main matrix used for the preparation of probiotic food products is the milk, because of the high compatibility between its chemical composition and the needs of the microorganisms' metabolism. Besides, this process results in products with great sensory acceptance and outstanding nutritional quality, with emphasis on yogurt and fermented milk (LUCATTO et al., 2020). However, the use of proteins and plant-origin components for food processing is constantly expanding, due to the increase in lactose intolerance and allergy to milk proteins cases, besides veganism and strict vegetarianism adhesion (KANDYLIS et al., 2016).

So-called "vegetable milks" have emerged as a market and consumer trend, prompting industries to seek alternatives free of animal components to meet these specific publics' demands. These "milks" presents remarkable biological quality due to the presence of fibers, minerals, unsaturated fatty acids, vitamin B, and isoflavones (IÇIER et al., 2015). Among the options available at the market, the use of oilseeds as raw material stands out. The Brazil nut (Bertholletia excelsa H.B.K) is naturally occurring in the Amazon region, has pleasant sensory characteristics and high nutritional and biological quality. Although, it is mainly consumed dehydrated or in low added value compositions. Even though few studies on the use of Brazilian nuts for the elaboration of fermented drinks are available, this oleaginous appears like an excellent alternative for the development of new products (YANG, 2009).

In this context, this study aimed to develop and characterize a drink based on Brazil nuts fermented by Lactobacillus casei with inulin addition. The survival rates of probiotic microorganisms after exposure to in vitro gastrointestinal tract conditions and sensory acceptance were also evaluated.

\section{MATERIALS AND METHODS}

\section{Raw materials (basic ingredients)}

Brazil nuts were collected from the Chico Mendes Extractive Reserve (10 $06^{\circ} 11^{\prime \prime}$ at $10^{\circ} 58^{\prime}$ 39" south latitude and $67^{\circ} 56^{\prime} 13^{\prime \prime}$ a $69^{\circ} 48$ '00" west longitude), in the Xapuri region, Acre, Brazil. Citrus pectin and demerara sugar were obtained from local markets (Seropédica, RJ, Brazil). Inulin prebiotic fiber was supplied by Sweetmix ${ }^{\circledR}$. FD-DVS nu$\operatorname{trish}^{\circledR}$ LC 01, a lyophilized culture of single strain (Lactobacillus casei $01^{\circledR}$ ) from Christian Hansen, Valinhos, Brazil, was used as the probiotic.

\section{Preparation of the symbiotic Brazil nut drink (SBND)}

The drink was prepared from the adaptation of the procedures described by FELBERG et al. (2004). Nuts previously sanitized were ground in water using a high-speed industrial blender LI-1,5-N (Skymsen, Santa Catarina, Brazil) for 10 minutes, at a 1:4 ratio (Brazil nut: water). The obtained liquid was then filtered to remove coarse solids. Inulin $(2.5 \%$ $\mathrm{w} / \mathrm{v})$, pectin $(0.5 \% \mathrm{w} / \mathrm{v})$ and demerara sugar $(5 \% \mathrm{w} / \mathrm{v})$ were added to the Brazil nut drink and subjected to pasteurization at $80 \pm 1^{\circ} \mathrm{C}$ for 20 minutes. After heat treatment, the drink was cooled in an ice bath until reach $37{ }^{\circ} \mathrm{C}$. Subsequently, the Lactobacillus casei culture was added to the Brazil nut drink at an initial count of $6.50 \log \mathrm{CFU} \mathrm{g}^{-1}$, reached by the addition of $0.10 \mathrm{~g}$ of culture for $1.00 \mathrm{~L}$ of the drink. After that, the Brazil nut drink was incubated in an unventilated oven at $37{ }^{\circ} \mathrm{C}$, under anaerobic conditions, for 12 hours. After fermentation, the drink (SBND) was bottled in sterile glass bottles and subjected to maturation for 24 hours under refrigeration at $4 \pm 1{ }^{\circ} \mathrm{C}$. After maturation, the drink remained under refrigeration at $4{ }^{\circ} \mathrm{C}$ for further analyses. The fermented sample (SBND) was analyzed for physical-chemical and 
microbiological parameters after $0,7,14$, and 28 days of refrigerated storage. As a control, the same drink but non-fermented (NFD) was used. All assays were carried out in triplicate.

\section{Physical-chemical analyses}

Chemical composition

Moisture, lipids, proteins, ashes, soluble and insoluble fibers were determined according to the methodology stipulated by the Association of Official Analytical Chemists (AOAC, 2012). Total carbohydrates were determined by the phenol-sulfuric method, according to DUBOIS et al. (1956).

\section{Analysis of physical-chemical quality}

$\mathrm{pH}$ was determined using a digital potentiometer (Oharus Starter 2100, Canada). Acidity (LA) in terms of lactic acid was determined by the titrimetric method using $0.1 \mathrm{~N}$ sodium hydroxide solution as titrant and phenolphthalein ethanolic solution as an indicator, following the procedure indicated by the AOAC (2012). Soluble solid contents (SS) were determined using a manual refractometer (Instrutherm, Brazil). Instrumental color was determined by reflectance using a Color Quest XE equipment (Hunter Lab, Reston, USA).

\section{Microbiological analyses \\ Microbiological quality}

The microbiological quality of the drink was evaluated by the enumeration of molds and yeast, Salmonella spp. determination and. total and thermotolerant coliforms, following APHA (2001). The assays were performed at $0,7,14,21$, and 28 days.

\section{Enumeration of probiotic counts and survival after} gastrointestinal resistance in vitro

Lactobacillus casei counts were performed on Man, Rogosa and Sharpe (MRS) agar (Merck, Darmstadt, Germany), containing a $2 \% \quad \mathrm{w} / \mathrm{v}$ vancomycin sterile solution $(0.5 \mathrm{~mL}$ of solution in $1000 \mathrm{~mL}$ of agar). The micro drop technique was used, where $20 \mu \mathrm{L}$ aliquots were incubated in plates containing MRS agar, from serial dilutions in sterile peptone. Plates were then incubated at $37 \pm 1{ }^{\circ} \mathrm{C}$ in an unventilated oven for $72 \mathrm{~h}$ under anaerobic conditions (CHAVES et al., 1999). Lactobacillus case $i$ enumerations were performed at the following times: $0,7,14,21$, and 28 days.

Gastrointestinal tract conditions in vitro simulation will be performed based on the adaptation of FAVARIN et al. (2015) methodologies in times 0 and 28 days. The simulation was performed in two stages (gastric and enteric), the second stage is divided into two stages.

The gastric phase started by exposing the drink to a $\mathrm{KCl}\left(1.12 \mathrm{~g} \mathrm{~L}^{-1}\right), \mathrm{NaCl}\left(2.00 \mathrm{~g} \mathrm{~L}^{-1}\right)$ and $\mathrm{NaH}_{2} \mathrm{PO}_{4}\left(0.40 \mathrm{~g} \mathrm{~L}^{-1}\right)$ sterile solutions, added mucin III (Sigma-Aldrich, St. Louis, MO, USA) at $3.50 \mathrm{~g} \mathrm{~L}^{-1}$ and purified pepsin (Sigma-Aldrich, St. Louis, MO, USA) at $0.26 \mathrm{~g} \mathrm{~L}^{-1}$. The solution $\mathrm{pH}$ was adjusted to the range of $1.4-1.9$ by the addition of concentrated $\mathrm{HCl}$. The enteric phase, which had two stages, was simulated by exposure to the bile solution (Sigma-Aldrich, St. Louis, MO, USA) and pancreatin (Sigma-Aldrich, St. Louis, MO, USA), with concentrations of $10 \mathrm{~g} \mathrm{~L}^{-1}$ and $1.95 \mathrm{~g} \mathrm{~L}^{-1}$, respectively. The differentiation of the steps was performed by the operating $\mathrm{pH}$ of the assay. In the first stage, the $\mathrm{pH}$ of the bile and pancreatin solution was adjusted to a range of $4.30-5.20$, using $\mathrm{NaHCO}_{3}$. In the second stage, the range used was $6.5-7.5$, also adding $\mathrm{NaHCO}_{3}$ for correction.

The entire simulation was carried out under constant agitation $(50 \mathrm{rpm})$ in a refrigerated shaker incubator NT 715 (Novatecnica, Rio de Janeiro, Brazil) at $37{ }^{\circ} \mathrm{C}$. Aliquots were removed at times 0 , 30, 60, 120 (gastric phase), 180, 240 (enteric phase - first stage), 300, and 360 minutes (enteric phase - second stage) of simulation to assess the in vitro Lactobacillus casei survival during the exposure to gastrointestinal tract conditions through micro drop counting technique (CHAVES et al., 1999), totaling 6 hours of procedure simulating the digestive process.

\section{Sensory evaluation}

The hedonic test (Global acceptance; Fermented aroma; Sweetness; Brazil nut flavor; Fermented flavor) was performed by 60 untrained volunteers (31 women, 29 men, aged 18-60 years) using a 9-point structured hedonic scale (9 - I liked it very much and 1 - I was very displeased). $30 \mathrm{~mL}$ of the sample, at approximately $4 \pm 1{ }^{\circ} \mathrm{C}$, were presented in a white plastic cup, coded with random three-digit numbers (BIANCHI et al., 2014).

\section{Statistical analysis}

An analysis of variance (ANOVA) test was applied to compare the effects of the different treatments, and the Tukey test was used to determine the difference between treatments, both at a confidence interval of 5\% (p-value). Statistical analyses were performed using the STATISTICA 7.0 software (StatiSoft, Inc., Tulsa, Okla., USA). All tests were carried out in triplicate and the results presented as means \pm standard deviation. 


\section{RESULTS AND DISCUSSION}

\section{Physical-chemical analyses Chemical composition}

The lipid, protein, carbohydrate, ash, and fiber contents for NFD and SBND were determined on a wet basis (Table 1). No significant differences were observed in the levels of lipids and proteins, at a significance level of 5\%. PUERARI et al. (2015) when studying chicha, a fermented rice-based beverage produced by Amerindian Brazilians, also reported that the amount of lipids and proteins were not altered, even after 36 hours' fermentation process, corroborating the results obtained in the present study for these nutrients. The study conducted by OJOKOH \& OREKOYA (2016) partially agrees with the stability of these nutrients during the vegetable fermentation process. When evaluating the effect of fermentation on the nutritional composition of watermelon's epicarp, the authors reported stability in the lipid content even after 96 hours of fermentation. However, concerning protein content, a slight increase was observed over the period. Such differentiation can be related to several aspects that can result in different responses, such as microorganism involved, concentration and availability of nutrients, presence of more fermentable compounds, and process conditions ( $\mathrm{pH}$ of the medium, temperature, time, availability or absence of oxygen) (SENDRA et al., 2016).

Although, significant changes have not been detected in the levels of lipids and proteins through the techniques applied, the profile of fatty acids and amino acids may have changed due to the fermentation process. According to FERRI et al. (2016), during the fermentation process, low molecular weight compounds can be formed, impacting directly the nutritional and biological quality of the products. Additionally, these compounds have an intrinsic relationship with the sensory characteristics of fermented foods. Thus, in future studies, a broader and more specific investigation of possible changes in protein and lipid fractions are indicated.
A significant change ( $p$-value $>0.05)$ in centesimal composition was observed after fermentation regarding fiber, ash, total carbohydrates, and moisture content.

The lactobacillus metabolism during the fermentation process resulted in a fiber decay. In general, fibers are degraded and converted into nutrients that favor lactic acid bacteria development. In a study on the influence of inulin, a recognized dietary fiber, on the development of Lactobacillus rhamnosus as a co-culture of Streptococcus thermophilus, OLIVEIRA et al. (2012) reported that inulin can stimulate the microorganisms' growth, providing the growth of microbial biomass. The authors also stated that this fiber can be used as an additional source of carbon and energy, to obtain better conditions for the fermentation process. The metabolism of fibers by Lactobacillus during the fermentation process is a very important aspect. According to DAHL et al. (2017), a fermentation of this component can cause the release of metabolites which can reduce the risk of diseases and provide some therapeutic benefits.

Similar to fibers, total carbohydrates concentration also decayed. Carbohydrates were enzymatically hydrolyzed, resulting in the release of less complex sugars, easily used by Lactobacillus case $i$ as an energy source during its multiplication and development (KAPRASOB et al., 2017). COSTA et al. (2013) also verified the reduction of the carbohydrate content when studying the cultivation of Lactobacillus casei in pineapple juice for a drink development. According to the authors, the saccharides' hydrolysis, such as sucrose, leads to sugars release, such as glucose and fructose, which can be easily assimilated by probiotic microorganisms. PUERARI et al. (2015) also observed a reduction in the concentration of complex carbohydrates in rice fermentation. Again, this study corroborated the results described by OJOKOH \& OREKOYA (2016), who also observed a reduction in the total carbohydrate content after the fermentation process of watermelon's epicarp. In the

Table 1 - Chemical composition of non-fermented drink (FND) e symbiotic Brazil nuts drink (SBND).

\begin{tabular}{lcccrrr}
\hline & Moisture $^{*}$ & Lipid $^{*}$ & Protein $^{*}$ & Total carbohydrate $^{*}$ & Fiber $^{*}$ & Ash $^{*}$ \\
\hline NFD & $73.06^{\mathrm{b}} \pm 0.06$ & $11.76^{\mathrm{a}} \pm 2.71$ & $3.31^{\mathrm{a}} \pm 0.55$ & $8.63^{\mathrm{a}} \pm 0.94$ & $3.11^{\mathrm{a}} \pm 1.26$ & $0.13^{\mathrm{a}} \pm 0.02$ \\
SBND & $81.35^{\mathrm{a}} \pm 0.02$ & $11.75^{\mathrm{a}} \pm 0.07$ & $3.01^{\mathrm{a}} \pm 0.70$ & $1.39^{\mathrm{b}} \pm 0.15$ & $2.42^{\mathrm{b}} \pm 0.10$ & $0.08^{\mathrm{b}} \pm 0.03$ \\
\hline
\end{tabular}

${ }^{*}$ Contents in $\mathrm{g} / 100 \mathrm{~g}$ of drink. ${ }^{\mathrm{a}-\mathrm{b}}$ Different letters in same column mean significant difference $(p$-value $>0.05)$. 
development of probiotic drinks made from lychee juice, ZHENG et al. (2014) reported a significant reduction in the total carbohydrate content, due to the metabolism of Lactobacillus casei. According to the authors, the reduction in carbohydrate content can be justified by the ability of $L$. casei to produce enzymes that can transform these nutrients into fermentable molecules.

It is worth mentioning that studies are needed with the use of more sensitive techniques, such as High Performance Liquid Chromatography - HPLC, to assess the kinetics of carbohydrates' transformation during the fermentation process, quantify and verify the consumption of fermentable sugars released after the hydrolytic process, and study the degradation of the fibers by the metabolism of Lactobacillus casei.

Regarding mineral content, a 38.5\% decrease was observed after fermentation. According to WALKER (2004), even at reduced concentrations, minerals are extremely important for microorganism multiplication, since it is associated with several enzymatic reactions, therefore, justifying its consumption in such a noteworthy manner.

\section{Physical-chemical quality}

The $\mathrm{pH}$ changes were evaluated in the SBND after 12 hours of fermentation ( 0 days) and in the other storage times - 7, 14, 21, and 28 days (Table 2). Significant differences were observed ( $p$-value $>0.05$ ) between 7 and 14 days and between 21 and 28 days of storage. For the control sample (FND), there were no significant changes in $\mathrm{pH}$ values, at a significance level of $5 \%$. The observed $\mathrm{pH}$ decrease is similar to the results reported by BEDANI et al. (2013), who also verified the reduction in $\mathrm{pH}$ values during refrigerated storage of a soy-based product fermented by Lactobacillus acidophilus and Bifidobacterium animalis. COSTA et al. (2017) evaluated the $\mathrm{pH}$ of a drink made from rice and soy processing byproducts fermented by Streptococcus thermophilus, Bifidobacterium spp, and Lactobacillus acidophilus and also reported a reduction in this parameter after 28 days of storage under refrigeration. According to FARNWORTH et al. (2007) and WANG et al. (2009), changes in $\mathrm{pH}$ values during storage are related to the post-acidification process, which is observed because of the continuous production of organic acids that occurs due to the metabolism of fermentable carbohydrates by the microorganisms.

SBND acidity was also determined at 0 , $7,14,21$, and 28 days of storage and expressed in lactic acid concentrations (Table 2). A slight increase in lactic acid content was observed, significantly higher ( $p$-value $>0.05$ ) from the 14th day of storage. Changes in the acidity of SBND are complementary to pH changes. MATEJČEKOVÁ et al. (2017) observed similar behavior when manufacturing products with buckwheat fermented with Lactobacillus rhamnosus. According to the authors, changes in the acidity of fermented products were due to the metabolic activity of probiotics, in particular by the generation of organic acids. LU et al. (2018) also observed an increase in acidity of a fermented vegetable drink made with durian pulp and selected probiotics and yeasts. Still in this study, it was observed that the change in acidity is due to the production of various organic acids, such as malic, citric, and acetic. This aspect is of great importance since Lactobacillus casei (microorganism used in the present study) is an optional heterofermentative and can produce several compounds in addition to lactic acid, which can affect the acidity of the drink (HILL et al., 2018).

Table 2 - Values of $\mathrm{pH}$, soluble solids (SS) and acidity in lactic acid (LA) of non-fermented drink (NFD) and symbiotic Brazil nuts drink (SBND).

\begin{tabular}{|c|c|c|c|c|c|c|}
\hline \multirow[t]{2}{*}{ Days of storage ${ }^{*}$} & \multicolumn{2}{|c|}{------------------pH------------------' } & \multicolumn{2}{|c|}{------------SS ('Brix)------------ } & \multicolumn{2}{|c|}{----LA (g/100 mL)-- } \\
\hline & NFD & SBND & NFD & SBND & NFD & SBND \\
\hline 0 days & $6.13^{\mathrm{Ab}} \pm 0.09$ & $5.56^{\mathrm{Ba}} \pm 0.04$ & $10.50^{\mathrm{Ba}} \pm 0.00$ & $11.00^{\mathrm{Aa}} \pm 0.00$ & $0.09^{\mathrm{Aa}} \pm 0.02$ & $0.12^{\mathrm{Ac}} \pm 0.01$ \\
\hline 7 days & $6.01^{\mathrm{Ab}} \pm 0.12$ & $5.52^{\mathrm{Ba}} \pm 0.01$ & $10.50^{\mathrm{Ba}} \pm 0.00$ & $11.00^{\mathrm{Aa}} \pm 0.00$ & $0.10^{\mathrm{Aa}} \pm 0.01$ & $0.12^{\mathrm{Ac}} \pm 0.01$ \\
\hline 14 days & $\mathrm{n} / \mathrm{a}^{* *}$ & $5.28^{\mathrm{b}} \pm 0.02$ & $\mathrm{n} / \mathrm{a}^{* *}$ & $12.17^{\mathrm{b}} \pm 0.29$ & $\mathrm{n} / \mathrm{a}^{* *}$ & $0.14^{\mathrm{bc}} \pm 0.02$ \\
\hline 21 days & $\mathrm{n} / \mathrm{a}^{* *}$ & $5.27^{b} \pm 0.04$ & $\mathrm{n} / \mathrm{a}^{* *}$ & $12.50^{\mathrm{b}} \pm 0.00$ & $\mathrm{n} / \mathrm{a}^{* *}$ & $0.17^{\mathrm{ab}} \pm 0.01$ \\
\hline 28 days & $\mathrm{n} / \mathrm{a}^{* *}$ & $5.16^{\mathrm{c}} \pm 0.01$ & $\mathrm{n} / \mathrm{a}^{* *}$ & $12.33^{b} \pm 0.58$ & $\mathrm{n} / \mathrm{a}^{* *}$ & $0.19^{\mathrm{a}} \pm 0.00$ \\
\hline
\end{tabular}

${ }^{*}$ Storage under refrigeration $\left(4 \pm 1{ }^{\circ} \mathrm{C}\right) .{ }^{* *}$ Tests not performed due to the growth of fungi visible to the naked eye. ${ }^{\mathrm{a}-\mathrm{c}}$ Different letters in the same column for the same parameter mean a significant difference ( $\mathrm{p}$-value $>0.05$ ). ${ }^{\mathrm{A}-\mathrm{B}}$ Different letters in the same line for the same parameter mean a significant difference ( $p$-value $>0.05$ ). 
Increased levels of soluble solids were also observed for the fermented drink during storage, with significant differences ( $p$-value $>0.05$ ) observed only between 7 and 14 days of storage (Table 2). As previously described, changes were observed in $\mathrm{pH}$ and acidity of the drink. It is known that acidity and $\mathrm{pH}$ are factors that affect the solubility of components (DAMADORAN et al., 2010). Thus, the presence of organic acids in the medium has a direct impact on the solubility of compounds; consequently, affecting the soluble solids content.

Concerning instrumental color, significant changes ( $p$-value $>0.05$ ) were observed for all analyzed parameters $\left(\mathrm{L}^{*}, \mathrm{a}^{*}, \mathrm{~b}^{*}\right.$, and, consequently, $\mathrm{C}^{*}$ ). Increases noted for $\mathrm{b}^{*}$ between 21 and 28 days are noteworthy, indicating that the drink became more yellow during storage (Table 3 ). Increase in yellow color intensity may be caused by oxidative and non-oxidative reactions involving lipids and polyphenols, generating colored condensation compounds. Besides, the formation of colored products by the Maillard reaction or by the generation of melanoidines is also possible, albeit more discreetly (TAJCHAKAVIT et al., 2001).

\section{Microbiological analyses \\ Analysis of microbiological quality}

During the fermented drink storage time of 28 days, the growth of characteristic colonies of molds and yeasts on the dextrose agar-potato was not observed. Salmonella spp. was also not detected. The enumeration of total and thermotolerant coliforms indicated satisfactory levels throughout the storage period (Table 4). However, for the control sample, it was observed the appearance of fungi visible to the naked eye, which made it impossible to analyze the control sample at the other storage times $(14,21$, and 28 days). According to MCDONALD et al. (1990), lactic acid bacteria (the group to which Lactobacillus casei belongs) tend to dominate the fermentative process of vegetables, due to its elevated tolerance to acidic medium, in addition to the capability of metabolizing different carbohydrates. According to PUERARI et al. (2015), the $\mathrm{pH}$ reduction by increasing the concentration of organic acids from the metabolism of lactic acid bacteria has an inhibitory effect on the development of deteriorating and pathogenic microorganisms. CAPLICE \& FITZGERALD (1999) reported that $\mathrm{pH}$ variation has a direct impact on the cell membrane of these microorganisms, which results in the inhibition of substance transport and modification of intracellular $\mathrm{pH}$, causing the inability to perform several metabolic activities, and consequently, preventing the development of microorganisms such as Salmonella, coliforms, and molds.

Although, the current Brazilian legislation does not present microbiological standards established for fermented drinks of vegetable origin. From Resolution RDC ${ }^{\circ}$ 12/2001, of the National Health Surveillance Agency (ANVISA), it is possible to make an association with the stipulated standards for products of the same category, origin and / or obtained by similar processing. According to this resolution, fermented milks kept under refrigeration must have maximum counts of $10 \mathrm{MPN} \mathrm{mL}^{-1}$ for thermotolerant coliforms, while fermented milk drink also kept under refrigeration must have maximum counts of $10 \mathrm{MPN}$ $\mathrm{mL}^{-1}$ for thermotolerant coliforms and absence of Salmonella spp. in $25 \mathrm{~mL}$. As for walnuts, a category to which Brazil nuts belongs, the established parameters are maximum enumeration of thermotolerant coliforms of $10^{3} \mathrm{MPN} \mathrm{mL}^{-1}$ and absence of Salmonella spp. Non-fermented beverages based on soy extract must have thermotolerant coliforms in concentration below $10 \mathrm{MPN} \mathrm{mL}^{-1}$ and absence of Salmonella spp. in 25

Table 3 - Color parameters of non-fermented drink (FND) e symbiotic Brazil nuts drink (SBND).

\begin{tabular}{|c|c|c|c|c|c|c|}
\hline c & & -------------- & -De & storage ${ }^{*}-$ & & ---- \\
\hline \multirow{2}{*}{ Parameters } & \multirow{2}{*}{ Control (FND) } & \multicolumn{5}{|c|}{ } \\
\hline & & 0 days & 7 days & 14 days & 21 days & 28 days \\
\hline$L^{*}$ & $72.65^{\mathrm{c}} \pm 0.38$ & $74.40^{\mathrm{b}} \pm 0.94$ & $74.79^{b} \pm 0.52$ & $74.64^{b} \pm 0.14$ & $77.29^{\mathrm{a}} \pm 1.10$ & $85.23^{\mathrm{a}} \pm 0.92$ \\
\hline$a^{*}$ & $-0.18^{a} \pm 0.05$ & $0.03^{\mathrm{a}} \pm 0.07$ & $-0.36^{b} \pm 0.09$ & $-0.30^{\mathrm{b}} \pm 0.05$ & $-0.38^{b} \pm 0.03$ & $-0.11^{\mathrm{a}} \pm 0.37$ \\
\hline$b^{*}$ & $4.09^{\mathrm{d}} \pm 0.06$ & $5.07^{b} \pm 0.19$ & $4.63^{c} \pm 0.10$ & $4.19^{c} \pm 0.01$ & $4.14^{\text {cd }} \pm 0.08$ & $7.44^{\mathrm{a}} \pm 0.86$ \\
\hline$C^{*}$ & $4.10^{\mathrm{d}} \pm 0.07$ & $5.07^{b} \pm 0.18$ & $4.35^{\mathrm{c}} \pm 0.16$ & $4.20^{c} \pm 0.01$ & $4.16^{\mathrm{cd}} \pm 0.08$ & $7.45^{\mathrm{a}} \pm 0.86$ \\
\hline$h^{\circ}$ & $92.52^{b} \pm 0.77$ & $89.71^{c} \pm 0.82$ & $94.64^{\mathrm{a}} \pm 1.04$ & $94.12^{\mathrm{a}} \pm 0.69$ & $95.21^{\mathrm{a}} \pm 0.30$ & $88.85^{c} \pm 2.82$ \\
\hline
\end{tabular}

${ }^{*}$ Storage under refrigeration $\left(4 \pm 1{ }^{\circ} \mathrm{C}\right) .{ }^{\mathrm{a}-\mathrm{c}}$ Different letters in the same line mean significant difference (p-value $\left.>0.05\right)$. 
Table 4 - Microbiological quality and enumeration of probiotic count drinks of non-fermented drink (FND) e symbiotic Brazil nuts drink (SBND).

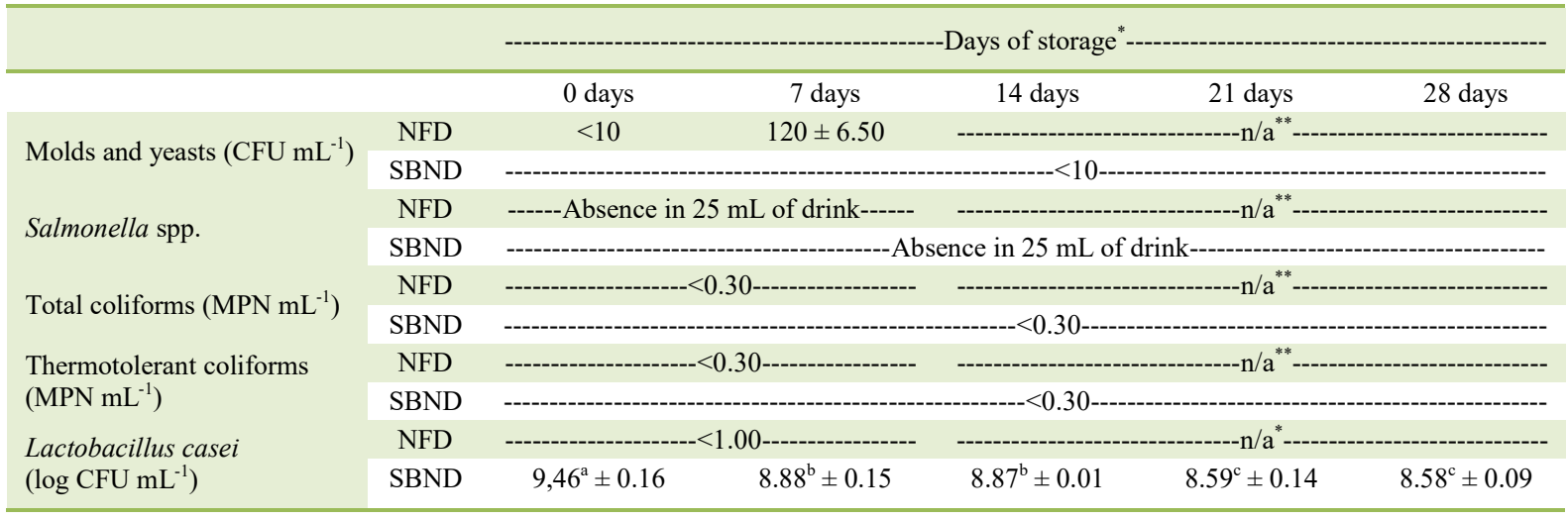

${ }^{*}$ Storage under refrigeration $\left(4 \pm 1{ }^{\circ} \mathrm{C}\right) .{ }^{* *}$ Tests not performed due to the growth of fungi visible to the naked eye. ${ }^{\mathrm{a}-\mathrm{c}}$ Different letters in the same line mean significant difference $(\mathrm{p}$-value $>0.05)$.

$\mathrm{mL}$, in addition to maximum counts of $5.10^{2} \mathrm{MPN}$ $\mathrm{mL}^{-1}$ for Bacillus cereus (BRASIL, 2001). This last microorganism is not characteristic of growth in the matrix used and for this reason its research was not carried out in the present study. Although, not required for any of the products presented here, the quantification of molds and yeasts was carried out, since fungi are the main responsible for the deterioration of Brazil nuts. It is possible to observe that SBND presented results capable of meeting the parameters of the products presented here.

Through the above, the combination of preservation methods (pasteurization and storage under refrigeration) and fermentation was satisfactory for maintaining the microbiological quality of the fermented drink. Product's safety is fundamentally associated with the production of organic acids by Lactobacillus casei (BLANDINO et al., 2003; PUERARI et al., 2015).

\section{Enumeration of probiotic counts and survival after gastrointestinal resistance in vitro}

The initial count of the lyophilized culture used to ferment the NFD was $6.50 \log \mathrm{CFU} \mathrm{mL} \mathrm{mL}^{-1}$. Lactobacillus casei presented counts ranging from 9.48 to $8.59 \log \mathrm{CFU} \mathrm{mL} \mathrm{mL}^{-1}$, with a $0.89 \log$ cycle reduction between 0 and 28 days of storage. Although the number of viable cells decreased during storage, the count was higher than $8.00 \log \mathrm{CFU} \mathrm{mL} \mathrm{m}^{-1}$, which is considered satisfactory for products fermented by probiotic microorganisms (Table 4). The development of Lactobacillus casei was not observed in the control sample.
CHAVAN et al. (2018) had similar results when making non-dairy fermented probiotic drinks from barley, ragi, moth bean, soybean, almond, and coconut, germinated and non-germinated. In all the plant matrices studied, the authors observed counts between 8 and $10 \log \mathrm{CFU} \mathrm{mL} \mathrm{mL}^{-1}$, confirming that vegetable matrices, such as oleaginous, nuts, fruits, and cereals, are suitable for the development of probiotics. MRIDULA \& SHARMA (2015) observed counts of Lactobacillus acidophilus greater than $10 \log \mathrm{CFU} \mathrm{mL} \mathrm{mL}^{-1}$ in the development of non-dairy probiotic drinks containing sprouted cereals, vegetables, and soy milk, showing that probiotic microorganisms are adaptable to vegetable matrices and can be incorporated into products free from animal origin ingredients, thus expanding the availability of food for individuals with dietary and/or ideological restrictions. CODA et al. (2012) observed a reduction in the Lactobacillus plantarum count over 30 days of storage of drinks made from cereals, soy flour, and more concentrated red grapes. According to the authors, the drinks had reductions between 0.4 and 0.7 logarithmic cycles, which corroborates with the present study, since during the storage of the fermented Brazil nut drink, it was observed a reduction of 0.88 logarithmic cycles over 28 days of storage. The stability of Lactobacillus casei during storage was also observed by NEMATOLLAHI et al. (2016), when incorporating L. casei in cornelian cherry juice stored under refrigeration. The recorded values were close to $8.00 \log \mathrm{CFU} \mathrm{mL} \mathrm{m}^{-1}$. The authors stated that such behavior is an important indicator for 
the use of microorganisms in the industrialization of differentiated plant matrices.

The viability of Lactobacillus casei was assessed after exposure to gastrointestinal tract conditions during 360 minutes at 0 and 28 days of storage. At 0 days of storage, Lactobacillus casei presented higher resistance to the established experimental conditions concerning the gastric phase $(0,30,60$, and 120 minutes of exposure), in which only a $0.24 \mathrm{log}$ cycle reduction was observed. However, during the two stages of the enteric phase $(180,240$, 300 , and 360 minutes), an expressive decrease on the viability of this microorganism was noted, with a 5.20 log cycle reduction compared to the initial count. The assessment carried out at 28 days of storage presented a different profile, once a $1.7 \mathrm{log}$ cycle reduction was observed in the first 30 minutes of the gastric phase, ending this phase with a $2.54 \mathrm{log}$ cycle variation. However, Lactobacillus casei behavior during the enteric phase presented a 4.37 log cycle reduction compared to the initial number of viable colonies, which is lower than the reduction observed for this phase at 0 days of storage (Figure 1).

CÉSPEDES et al. (2014) evaluated L. casei LC-01 and L. casei BGP 93 survival during the in vitro gastrointestinal tract conditions simulation and also observed significant microorganisms viability reductions. The authors reported that; although, the strains used in the study had already been documented and identified as resistant to gastrointestinal conditions, the conditions applied in the fermentation process and matrix used could affect the probiotic count's maintenance. CHAMPAGNE \& GARDNER (2008) also reported similar results when assessing the impact of refrigerated storage and exposure to gastrointestinal drastic stresses for Lactobacillus strains incorporated into fruit drinks, in which viability reductions of the studied microorganisms were observed. According to NEMATOLLAHI et al. (2016), the viability of probiotics can also be affected by inhibitors used during fermentation, $\mathrm{pH}$, accumulation of organic acids, and cold storage.

Even with counts above $8.00 \log \mathrm{CFU} \mathrm{mL} \mathrm{m}^{-1}$ during the 28 days of drink storage, a drastic reduction of viable cells number was observed after exposure to gastrointestinal tract conditions. Thus, the components of the applied matrix did not exert a protective effect on Lactobacillus casei. It is also noteworthy that the drink contains inulin, a polysaccharide with a recognized protective effect, which was still not able to exert a beneficial effect on microorganism maintenance during its in vitro exposure to the gastric and enteric phases. However, even with the $L$. casei viability reduction after the in vitro exposure to gastrointestinal tract conditions, SBND may be considered a functional product. According to CASAROTTI et al. (2014) and ESPITIA et al. (2016), benefic effects to human health can be observed when the probiotic microorganism reaches the intestine with a minimum count of 6.00 $\log \mathrm{CFU} \mathrm{mL} \mathrm{m}^{-1}$, as observed in this study.

Changes in the preparation of the drink can be applied to provide greater resistance to

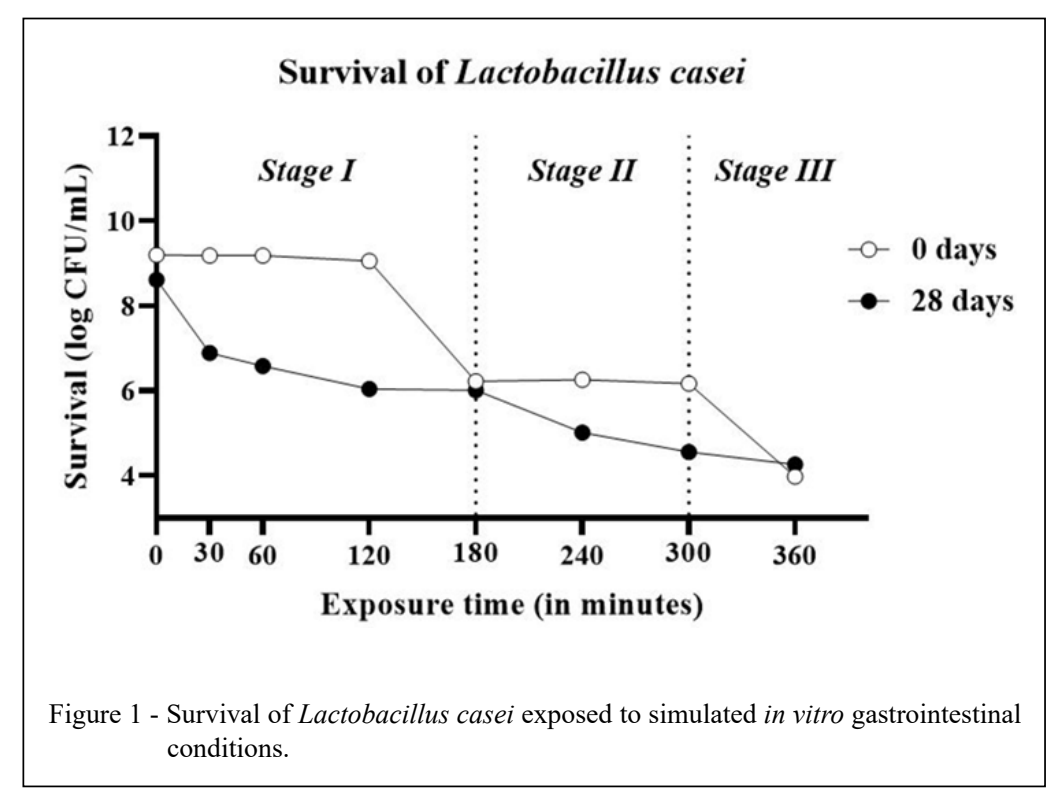

Ciência Rural, v.51, n.2, 2021. 
gastrointestinal tract conditions. According to LORCA \& VALDEZ (2001), the development and growth of microorganisms in environments with lower $\mathrm{pH}$ provides greater tolerance to acids. In the present study, the elaborated drink had a $\mathrm{pH}$ between 5.56 and 5.16, which was not enough for such tolerance development. Thus, a possibility is the acidification of the Brazil nut extract before the fermentation process, to achieve a possible induction in the Lactobacillus resistance to $\mathrm{pH}$ changes, and consequently, improving its survival during the exposure to the gastrointestinal tract.

Another alternative is the application of microencapsulation techniques on probiotic microorganisms. HADZIEVA et al. (2017) evaluated the stability and resistance to the gastrointestinal tract conditions of a Lactobacillus casei strain microencapsulated in alginate and soy proteins isolate. The study indicated that microencapsulation contributed to maintaining viability, with stable counts

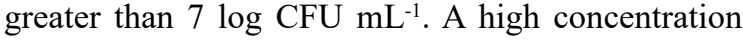
of Lactobacillus was also observed in the intestinal phase. CHAIKHAM et al. (2013) compared micro-encapsulated microorganisms (Lactobacillus acidophilus LA5 and Lactobacillus casei 01) survival in processed juices after exposure to gastrointestinal tract conditions. Both microorganisms, when microencapsulated, showed resistance to the in vitro conditions of the stomach and small intestine, while free microorganisms were eliminated still in the stomach phase, thus indicating a remarkable protective effect of microencapsulation on the microorganisms.

It is worth mentioning that recent studies indicate that the effect of probiotic microorganisms is not just based on viability and that benefits can be observed even with the presence of dead and inactive cells, in addition to metabolites and cellular components, as described by ZENDEBOODI et al. (2020). Thus, it is extremely important that in addition to alternatives to make Lactobacillus casei in the drink more viable and resistant, studies are carried out to evaluate the occurrence of beneficial effects even with the microorganism viability reduction.

Sensory evaluation
The sensory evaluation was carried out to verify consumer drink acceptance. SBND had the scores ranging from "neither liked nor disliked" to "liked slightly" based on the applied hedonic scale, while the control sample had scores ranging from "neither liked nor disliked" and "liked regularly". Significant differences were observed ( $p$-value $>0.05$ ) for the attributes "global acceptance", "fermented aroma" and "fermented flavor", indicating that the fermentation process caused alterations in the characteristics of the beverage linked to these parameters, affecting your acceptance. However; although, the control sample had scores slightly higher than the SBND for the attributes "sweetness" and "brazil nut flavor", they were not significantly different ( $p$-value $>0.05$ ) when compared to fermented drink (Table 5). According to HOLKEM et al. (2019), insertion of a new product, qualifying the consumer as not yet familiar, may cause doubts regarding the sensory evaluation.

For SBND, the attributes that presented lower scores were overall acceptance and fermented flavor. Middle-ranged scores probably occurred because the developed drink presents singular characteristics, far from the sensory memory of the participants. The overall SBND acceptance was average. ILYASOĞLU et al. (2014) developed a yogurt-type product from hazelnut slurry and had a sensory evaluation similar to the obtained in this study. The authors analyzed the attributes appearance, consistency, odor, taste and, overall acceptability, obtaining scores between 4.29 and 5.42, also using a nine-point scale. It is worth mentioning that, for the general/global acceptance attribute, SBND was better evaluated, with a 5.49 score, while a product prepared by ILYASOĞLU and collaborators (2014) received a 4.81 .

Results achieved in this study corroborated with the results obtained by CRUZ et al. (2010), who emphasized that the sensory characteristics of a product, mainly flavor and aroma, can be negatively affected by components produced by the metabolism of the probiotic microorganisms during the fermentation process.

Table 5 - Sensory Evaluation of non-fermented drink (FND) e symbiotic Brazil nuts drink (SBND).

\begin{tabular}{lccccc}
\hline & Global Acceptance & Fermented Aroma & Sweetness & \multicolumn{2}{c}{ Brazil Nut Flavor } \\
\hline NFD & $6.58^{\mathrm{a}} \pm 2.11$ & $6.81^{\mathrm{a}} \pm 1.65$ & $6.20^{\mathrm{a}} \pm 2.48$ & $6.17^{\mathrm{a}} \pm 2.33$ & $5.70^{\mathrm{a}} \pm 2.24$ \\
SBND & $5.49^{\mathrm{b}} \pm 2.39$ & $5.80^{\mathrm{b}} \pm 2.28$ & $5.63^{\mathrm{a}} \pm 2.39$ & $6.02^{\mathrm{a}} \pm 2.32$ & $5.42^{\mathrm{b}} \pm 2.37$ \\
\hline
\end{tabular}

${ }^{a-b}$ Different letters in the same line mean significant difference ( $p$-value $\left.>0.05\right)$. 
The SBND sensory characteristics can also be improved with adjustments in its elaboration. CHAVAN et al. (2018) performed a sensory evaluation with drinks made with different vegetable matrices. Products made with barley, ragi, and moth, when mixed with soy, almond, and coconut extracts, separately, showed higher scores than those made only with water. Therefore, the sensory quality of SBND could be improved with the use of other ingredients to replace water. The application of masking techniques, such flavoring with fruits, chocolate, vanilla, and others, can have a positive effect on the hedonic quality of the product, leading to items with therapeutic effects that also meet consumers' desires (KHERZI et al., 2016). Microencapsulation, a technique previously mentioned for improving the viability of Lactobacillus casei, can also bring benefits to the sensory quality of the product. GARCÍA-CEJA and collaborators (2015) evaluated the incorporation and stability of Lactobacillus microcapsules in several products, including peach nectar. Results in this plant matrix were promising, since, despite the perception of the capsules by the tasters, the nectar received evaluations above 6.00 (on a 9-point scale). The authors also added that the presence of capsules containing Lactobacillus did not alter the product's aroma, a considerable point in the present study once it received an evaluation of 5.80 for this attribute. PRAKASH et al. (2018) also reported positive experiences when incorporating microcapsules containing microorganisms in vegetable drinks. The authors reported great acceptability of a symbiotic drink made from litchi juice and microencapsulated Lactobacillus casei for the attributes color, taste, aroma, mouthfeel, and sensory quality attributes of the drink in general. Besides, it was reported the increased acceptability of the samples containing inulin.

Additionally, further studies are needed for a better understanding of the drink sensory profile, aiming to make future improvements. The determination of organic acids, volatile compounds, and fatty acid profile is necessary to detect the changes resulting from the fermentation process, to optimize changes in the preparation of the drink, as well as to know the impact of processing and fermentation on nutritional, biological and bioactive quality of the drink, besides its functional attributes. Finally, it is necessary to conduct more robust sensory assessments, with a greater basis in consumers' perception, such as Napping, Sorting, Check-all-apply (CATA), Free Listing, to promote the development of a product that meets consumer desires and needs.

\section{CONCLUSION}

Although, the milk bases are the most used matrices for the development of products involving Lactobacillus casei, this study showed the potential of substrates of vegetable origin, specially Brazil nuts, for the production of fermented drinks free of animal-origin components. The fermented drink obtained was stable, with 28 days' shelf life, when stored under refrigeration, revealing that the combination of different preservation methods was sufficient to guarantee the microbiological stability of the product without the use of chemical preservatives. Although changes in physical and chemical characteristics occurred after fermentation and during storage, the fermented product showed remarkable levels of lipids, proteins, and fibers. It should be noted that the raw material used has high nutritional quality, being a source of biologically active constituents.

Regarding the sensory evaluation, the elaborated drink presented intermediate scores. Thus, studies based on the consumer's perception of the product are necessary to promote improvements in their sensory profile. Additionally, tests are also needed to assess, in a more analytical way, the changes resulting from the fermentation process and its correlations with the sensory characteristics of the product. Another important aspect is the viability of Lactobacillus casei under the conditions of the gastrointestinal tract. Although, many authors report benefits caused by dead, inactive cells, and/or metabolites, it is essential to search for alternatives that allow $L$. casei to become more viable in the studied matrix, such as microencapsulation and optimization of the fermentation process.

The possibility of developing a symbiotic product, free of animal-origin ingredients, that does not violate the premises of dietary and/or ideological restrictions, without the addition of chemical additives, and made from a typical Brazilian raw material is promising.

\section{ACKNOWLEDGEMENTS}

The authors would like to thank the Conselho Nacional de Desenvolvimento Científico e Tecnológico (CNPq) for financial support (processes n. 472988/2014-0 and $n$. 443310/2016-5) and scholarship granted to researcher, Sweetmix ${ }^{\circledR}$, Embrapa Agroindústria de Alimentos, Programa de Pós-Graduação em Ciência e Tecnologia de Alimentos (PPGCTA - UFRRJ), PróReitoria de Pós-Graduação (PROPPG - UFRRJ), Universidade Federal Rural do Rio de Janeiro (UFRRJ). This sudy was financed in part by the Coordenação de Aperfeiçoamento de Pessoal de Nível Superior (CAPES), Brasil - Finance code 001. 


\section{BIOETHICS \\ AND \\ COMMITTEE APPROVAL \\ BIOSSECURITY}

The authors declare that the research project was approved by the Research Ethics Committee of the Universidade Federal do Estado do Rio de Janeiro (UNIRIO) under registration number CAAE - 93560518.6.0000.5285.

\section{DECLARATION OF CONFLICT OF INTERESTS}

The authors declare no conflict of interest. Sponsors had no role in the design of the study; in the collection, analysis or interpretation of data; in the writing of the manuscript and in the decision to publish the results.

\section{AUTHORS' CONTRIBUTIONS}

All authors contributed equally for the conception and writing of the manuscript. All authors critically revised the manuscript and approved of the final version.

\section{REFERENCES}

AOAC. Official methods of analysis of AOAC International: Agricultural Chemicals, Contaminants, Drugs. 2012, Gaithersburg: AOAC International.

APHA. Compendium of methods for the microbiological examination of foods, 2001. Washington: APHA International.

ASSMANN G. et al. Functional foods and cardiometabolic diseases: International Task Force for Prevention of Cardiometabolic Diseases. Nutrition, Metabolism and Cardiovascular Diseases, v.24, n.12, p.1272-1300, 2014. Available from: <https://www. sciencedirect.com/science/article/abs/pii/S0939475314003184>. Accessed: Jul. 29, 2020. doi: 10.1016/j.numecd.2014.10.010.

BEDANI, R. Impact of inulin and okara on Lactobacillus acidophilus La-5 and Bifidobacterium animalis $\mathrm{Bb}-12$ viability in a fermented soy product and probiotic survival under in vitro simulated gastrointestinal conditions. Food Microbiology, v.34, p.382-389, 2013. Available from: $<$ https:/www.sciencedirect.com/ science/article/pii/S0740002013000130?via\%3Dihub>. Accessed: Jul. 15, 2020. doi: 10.1016/j.fm.2013.01.012 .

BIANCHI, F. et al. Potentially synbiotic fermented beverage with aqueous extracts of quinoa (Chenopodium quinoa Willd) and soy. Food Science and Technology International, v.21, n.6, p.403-415, 2014 Available from: <https://www.ncbi.nlm.nih.gov/pubmed/24958776>. Accessed: Mar. 20, 2020. doi: 10.1177/1082013214540672.

BLANDINO, A. et al. Cereal-based fermented foods and beverages. Food Research International, v.36, p.527-543, 2003. Available from: <https://www.sciencedirect.com/science/article/ abs/pii/S0963996903000097>. Accessed: Aug. 02, 2020. doi: 10.1016/S0963-9969(03)00009-7.

BRASIL. Ministério da Saúde. Agência Nacional de Vigilância Sanitária - ANVISA. Resolução da Diretoria Colegiada - RDC n ${ }^{\circ}$ 12, de 02 de janeiro de 2001. Regulamento técnico sobre padrões microbiológicos para alimentos. Diário Oficial [da] República Federativa do Brasil, Brasília, 10/01/2001, n.7, s.1, 2001.
CAPLICE, E.; FITZGERALD, G. F. Food fermentations: role of microorganisms in food production and preservation. International Journal of Food Microbiology, v.50, p.131-149, 1999. Available from: <https:/www.sciencedirect.com/science/ article/abs/pii/S0168160599000823?via\%3Dihub>. Accessed: Aug. 02, 2020. doi: 10.1016/s0168-1605(99)00082-3.

CASAROTTI, S. N. et al. Evaluation of the effect of supplementing fermented milk with quinoa flour on probiotic activity. Journal of Dairy Science, v.97, p.6027-6035, 2014. Available from: <https:// www.ncbi.nlm.nih.gov/pubmed/25087036>. Accessed: Mar. 24, 2020. doi: 10.3168 / jds.2014-8197.

CESPEDES, M. et al. Performance in nondairy drinks of probiotic $L$. casei strains usually employed in dairy products. Journal of Food Science, v.78, n.5, p.M756-M762, 2013. Available from: <https:// onlinelibrary.wiley.com/doi/abs/10.1111/1750-3841.12092>. Accessed: Aug. 04, 2020. doi: 10.1111/1750-3841.12092.

CHAIKHAM, P. et al. Activities of free and encapsulated Lactobacillus acidophilus LA5 or Lactobacillus casei 01 in processed longan juices on exposure to simulated gastrointestinal tract. Journal of the Science of Food and Agriculture, v.93, n.9, p.2229-2238, 2013. Available from: <https://onlinelibrary.wiley. com/doi/abs/10.1002/jsfa.6030>. Accessed: Aug. 05, 2020. doi: $10.1002 /$ jsfa. 6030 .

CHAMPAGNE, C. P.; GARDNER, N. J. Effect of storage in a fruit drink on subsequent survival of probiotic lactobacilli to gastrointestinal stresses. Food Research International, v.41, p.539-543, 2008. Available from: <https://www.sciencedirect.com/science/ article/abs/pii/S0963996908000616>. Accessed: Aug. 05, 2020. doi: 10.1016/j.foodres.2008.03.003.

CHAVAN, M. et al. Development of non-dairy fermented probiotic drink based on germinated and ungerminated cereals and legume. LWT - Food Science and Technology, v.91, p.339-344, 2018. Available from: <https://www.sciencedirect.com/science/article/ pii/S0023643818301087?via\%3Dihub>. Accessed: Jan. 17, 2020. doi: 10.1016/j.lwt.2018.01.070.

CHAVES, A. H. et al. Effect of one strain of Lactobacillus acidophilus (LT 516) as probiotic for calves. Revista Brasileira de Zootecnia, v.28, n.5, p.1075-1085, 1999. Available from: $<$ https://www.scielo.br/scielo.php?script=sci_arttext\&pid=S151635981999000500025\&lang=en>. Accessed: Jun. 11, 2020. doi: $10.1590 / \mathrm{S} 1516-35981999000500025$.

CODA. R. et al. Yogurt-like beverages made of a mixture of cereals, soy and grape must: Microbiology, texture, nutritional and sensory properties. International Journal of Food Microbiology, v.155, n.3, p.120-127, 2012. Available from: <https://www.sciencedirect. com/science/article/abs/pii/S0168160512000451?via\%3Dihub>. Accessed: Aug. 04, 2020. doi: 10.1016/j.ijfoodmicro.2012.01.016.

COSTA, K. K. F. et al. Changes of probiotic fermented drink obtained from soy and rice byproducts during cold storage. LWT - Food Science and Technology, v.78, p.23-30, 2017. Available from: $\quad<$ https://www.sciencedirect.com/science/article/pii/ S0023643816307927?via\%3Dihub>. Accessed: Jul, 26, 2020. doi: 10.1016/j.lwt.2016.12.017.

COSTA, M. G. M. et al. Sonicated pineapple juice as substrate for L. casei cultivation for probiotic beverage development: Process optimisation and product stability. Food Chemistry, v.139, n.1-4, p.261-266, 2013. Available from: $<$ https://www.sciencedirect.com/ 
science/article/pii/S0308814613000836>. Accessed: Jul, 30, 2020. doi: 10.1016/j.foodchem.2013.01.059.

CRUZ, A. G. et al. Sensory analysis: Relevance for prebiotic, probiotic, and synbiotic product development. Comprehensive Reviews in Food Science and Food Safety, v.9, p.358-373, 2010. Available from: <https://onlinelibrary.wiley.com/doi/full/10 $.1111 /$ j.1541-4337.2010.00115.x>. Accessed: Feb. 02, 2020. doi: $10.1111 / \mathrm{j} .1541-4337.2010 .00115$

DAHL, W. J. et al. Health benefits of fiber fermentation. Journal of the American College of Nutrition, v.36, n.2, p.127-136, 2017. Available from: $<$ https://www.tandfonline.com/doi/abs/10.1080/0 7315724.2016.1188737? journalCode $=$ uacn20 $>$. Accessed: Jul. 30, 2020. doi: $10.1080 / 07315724.2016 .1188737$.

DAMADORAN, S. et al. Fennema's Food Chemistry. $4^{\circ}$ edição. Porto Alegre: Artmed, 2010. 900p.

DUBOIS, M. et al. Colorimetric method for determination of sugars and related substances. Analytical Chemistry, v.28, p.350356, 1956. Available from: <https://pubs.acs.org/doi/abs/10.1021/ ac60111a017>. Accessed: Mar. 14, 2020. doi: 10.1021/ ac60111a017.

ESPITIA, P. J. P. et al. Probiotics and their potential applications in active edible films and coatings. Food Research International, v.90, p.42-52, 2016. Available from: <https://doi.org/10.1016/j. foodres.2016.10.026>. Accessed: Jan. 17, 2020. doi: 10.1016/j. foodres.2016.10.026

FARNWORTH, E R. et al. Growth of probiotic bacteria and bifidobacteria in a soy yogurt formulation. International Journal of Food Microbiology, v.116, p.174-181, 2007. Available from: $\quad<\mathrm{https}: / / \mathrm{www} . s c i e n c e d i r e c t . c o m /$ science/article/abs/pii/ S016816050700030X?via\%3Dihub>. Accessed: Jul. 01, 2020. doi: 10.1016/j.ijfoodmicro.2006.12.015.

FAVARIN, L. et al. Survival of free and microencapsulated Bifidobacterium: effect of honey addition. Journal of Microencapsulation, v.32, p.329-335, 2015. Available from: $<$ https://www.ncbi.nlm.nih.gov/pubmed/25775038>. Accessed: Feb. 02, 2020. doi: 10.3109/02652048.2015.1017620.

FELBERG, I. et al. Mixed drink of integral soya extract and brazil nut: physical-chemical, nutritional characterization and consumer acceptability. Alimentos e Nutrição Araraquara, v.15, n.2, p.163-174, 2004. Available from: <https://www. alice.cnptia.embrapa.br/handle/doc/1122668>. Accessed: Jun. 18, 2020

FERRI M. et al. 2016. Improving the functional and sensorial profile of cereal-based fermented foods by selecting Lactobacillus plantarum strains via a metabolomics approach. Food Research International, v.89, n.3, p.1095-1105, 2016. Available from: $<$ https://www.sciencedirect.com/science/article/abs/pii/ S0963996916303878>. Accessed: Jul. 29, 2020. doi: 10.1016/j. foodres.2016.08.044.

GARCÍA-CEJA, A. et al. Viability during refrigerated storage in selected food products and during simulated gastrointestinal conditions of individual and combined lactobacilli encapsulated in alginate or alginate-chitosan. LWT - Food Science and Technology, v63, n.1, p.482-489, 2015. Available from: $<$ https://www.sciencedirect. $\mathrm{com} /$ science/article/pii/S0023643815002248?via\%3Dihub $>$. Accessed: Aug. 05, 2020. doi: 10.1016/j.lwt.2015.03.071.
GIBSON, G. R. et al. The International Scientific Association for Probiotics and Prebiotics (ISAPP) consensus statement on the definition and scope of prebiotics. Nature Reviews Gastroenterology \& Hepatology, v.14, p.491-502, 2017. Available from: <https://www.ncbi.nlm.nih.gov/pubmed/28611480>. Accessed: Mar. 28, 2020. doi: 10.1038 / nrgastro.2017.75.

GRANATO, D. et al. An integrated strategy between food chemistry, biology, nutrition, pharmacology, and statistics in the development of functional foods: A proposal. Trends in Food Science \& Technology, v.62, p.13-22, 2017. Available from: <https://www. sciencedirect.com/science/article/abs/pii/S0924224416303284>. Accessed: Jul. 29, 2020. doi: 10.1016/j.tifs.2016.12.010.

GRANATO, D. et al. Functional foods: Product development, technological trends, efficacy testing, and safety. Annual Review of Food Science and Technology, v.11, n.1, p.3.1-3.26, 2020. Available from: <https://www.annualreviews.org/doi/10.1146/ annurev-food-032519-051708>. Accessed: Jul. 18, 2020. doi: 10.1146/annurev-food-032519-051708.

HADZIEVA, J. et al. Lactobacillus casei encapsulated in soy protein isolate and alginate microparticles prepared by spray drying. Food Technology and Biotechnology, v.55, n.2, p.173-186, 2017. Available from: <https://pubmed.ncbi.nlm.nih.gov/28867947/>. Accessed: Aug. 05, 2020. doi: 10.17113/ftb.55.02.17.4991.

HILL, C. et al. The International Scientific Association for Probiotics and Prebiotics consensus statement on the scope and appropriate use of the term probiotic. Nature Reviews Gastroenterology \& Hepatology, v.11, p.506-514, 2014. Available from: <https:// www.nature.com/articles/nrgastro.2014.66>. Accessed: Jul. 29, 2020. doi: 10.1038/nrgastro.2014.66.

HILL. D. et al. The Lactobacillus casei group: history and health related applications. Frontiers in Microbiology, v.9, n.2107, p.1-12, 2018. Available from: <https://www.frontiersin.org/ articles/10.3389/fmicb.2018.02107/full>. Accessed: Aug. 03, 2020. doi: $10.3389 /$ fmicb.2018.02107.

HOLKEM, A. T. et al. Sugarcane juice with co-encapsulated Bifidobacterium animalis subsp. lactis BLC1 and proanthocyanidinrich cinnamon extract. Probiotics and Antimicrobial Proteins, p.1-14, 2019. Available from: <https://pubmed.ncbi.nlm.nih. gov/31709506/>. Accessed: Jul. 24, 2020. doi: 10.1007 / s12602019-09605-x.

IÇIER, F. et al. Changes on some quality characteristics of fermented soy milk beverage with added apple juice. LWT - Food Science and Technology, v.63, p.57-64, 2015. Available from: <https://www.sciencedirect.com//science/article/pii/ S0023643815002558?via\%3Dihub>. Accessed: Mar. 24, 2020. doi: $10.1016 / \mathrm{j} .1 \mathrm{wt} .2015 .0 . .3 .102$.

ILYASOĞLU, H. et al. Preliminary assessment of a yoghurt-like product manufactured from hazelnut slurry: Study using response surface methodology. LWT - Food Science and Technology, v.62, n.1, p.497-505, 2015. Available from: <https://www.sciencedirect. com/science/article/pii/S0023643814003764?via\%3Dihub>. Accessed: Aug. 05, 2020. doi: 10.1016/j.lwt.2014.06.023.

KANDYLIS, P. et al. Dairy and non-dairy probiotic beverages. Current Opinion in Food Science, v.7, p.58-63, 2016. Available from: <https://www.sciencedirect.com/science/article/abs/pii/ S2214799315001411?via\%3Dihub>. Accessed: Feb. 12, 2020. doi: 10.1016/j.cofs.2015.11.012 
KAPRASOB, R. et al. Fermentation-based biotransformation of bioactive phenolics and volatile compounds from cashew apple juice by select lactic acid bacteria. Process Biochemistry, v.59, p.141-149, 2017. Available from: <https:/www.sciencedirect. com/science/article/abs/pii/S1359511317302301?via\%3Dihub>. Accessed: Mar. 24, 2020. doi: 10.1016/j.procbio.2017.05.019.

KHERZI, S. et al. Fig juice fermented with lactic acid bacteria as a nutraceutical product. Pharmaceutical Sciences, v.22, p.260266, 2016. Available from: <https://ps.tbzmed.ac.ir/Article/ PHARM 3902 20160611084331>. Accessed: Mar. 24, 2020. doi: 10.15171/PS.2016.40.

KÜSTER-BOLUDA, I.; VIDAL-CAPILLA, I. Consumer attitudes in the election of functional foods. Spanish Journal of Marketing ESIC, v.21, p.65-79, 2017. Available from: $<$ https://www.elsevier. es/en-revista-spanish-journal-marketing-esic-377-articuloconsumer-attitudes-in-election-functional-S2444969517300604>. Accessed: Jan. 14, 2020. doi: 10.1016/j.sjme.2017.05.002.

LORCA, G. L.; VALDEZ, G. F. de. A Low-pH-inducible, stationaryphase acid tolerance response in Lactobacillus acidophilus CRL 639. Current Microbiology, v.42, p.21-25, 2001. Available from: <https://link.springer.com/article/10.1007/s002840010172>. Accessed: Aug. 03, 2020. doi: 10.1007/s002840010172.

LU, Y. et al. A novel non-dairy beverage from durian pulp fermented with selected probiotics and yeast. International Journal of Food Microbiology, v.265 p.1-8, 2018. Available from: <https:// pubmed.ncbi.nlm.nih.gov/29107841/>. Accessed: Apr. 23, 2020. doi: 10.1016/j.ijfoodmicro.2017.10.030.

LUCATTO, J. N. et al. Performance of different microbial cultures in potentially probiotic and prebiotic yoghurts from cow and goat milks. International Journal of Dairy Technology, v.73, n.1, p.144-156, 2020. Available from: $<$ https://onlinelibrary.wiley.com/ doi/full/10.1111/1471-0307.12655>. Accessed: Jul. 29, 2020. doi: 10.1111/1471-0307.12655.

MATEJČEKOVÁ, Z. et al. Functional probiotic products based on fermented buckwheat with Lactobacillus rhamnosus. LWT Food Science and Technology, v.81, p.35-41, 2017. Available from: $\quad<$ https://www.sciencedirect.com/science/article/pii/ S0023643817301639>. Accessed: Aug. 04, 2020. doi: 10.1016/j. lwt.2017.03.018

MCDONALD, L. C. et al. Acid tolerance of Leuconostoc mesenteroides and Lactobacillus plantarum. Applied and Environmental Microbiology, v.56, n.7, p.2120-2124. Available from: <https://pubmed.ncbi.nlm.nih.gov/16348238/>. Accessed: Aug. 03, 2020. doi: 10.1128/AEM.56.7.21202124.1990.

MRIDULA D.; SHARMA, M. Development of non-dairy probiotic drink utilizing sprouted cereals, legume and soymilk. LWT - Food Science and Technology, v.62, n.1, p.482-487, 2015. Available from: <https://www.sciencedirect.com/science/ article/pii/S0023643814004423>. Accessed: Apr. 23, 2020. doi: 10.1016/j.lwt.2014.07.011.

NEMATOLLAHI, A. et al. Viability of probiotic bacteria and some chemical and sensory characteristics in cornelian cherry juice during cold storage. Electronic Journal of Biotechnology, v.21, p.49-53, 2016. Available from: <https://www.sciencedirect.com/ science/article/pii/S0717345816300148?via\%3Dihub>. Accessed: Aug. 04, 2020. doi: 10.1016/j.ejbt.2016.03.001.
OJOKOH, A. O.; OREKOYA, E. S. Effect of fermentation on the proximate composition of the epicarp of watermelon (Citrullus lanatus). International Journal of Swarm Intelligence and Evolutionary Computation, v.5, n.3, p.1-5, 2016. Available from: $<$ https://www.longdom.org/open-access/effect-of-fermentationon-the-proximate-composition-of-the-epicarp-ofwatermeloncitrullus-lanatus-2090-4908-1000143.pdf >. Accessed: Jul. 21, 2020. doi: 10.4172/2090-4908.1000143.

OLIVEIRA, R. P. de S. Effect of inulin on the growth and metabolism of a probiotic strain of Lactobacillus rhamnosus in co-culture with Streptococcus thermophilus. LWT - Food Science and Technology, v.47, n.2, p.358-363, 2012. Available from: <https://www.sciencedirect.com/science/article/pii/ S0023643812000503>. Accessed: Jul. 21, 2020. doi: 10.1016/j. lwt.2012.01.031

PRAKASH, K. S. et al. Development of synbiotic litchi juice drink and its physiochemical, viability and sensory analysis. Journal of Food Processing \& Technology, v.8, n.12, p.1-6, 2018. Available from: <https://www.longdom.org/archive/jfpt-volume-8-issue-12year-2017.html>. Accessed: Aug. 02, 2020. doi: 10.4172/21577110.1000708 .

PUERARI, C. et al. 2015. Physicochemical and microbiological characterization of chicha, a rice-based fermented beverage produced by Umutina Brazilian Amerindians. Food Microbiology, 2015, v.46, p.210-217. Available from: $<$ https://www.sciencedirect.com/science/article/abs/pii/ S0740002014002081>. Accessed: Jul. 29, 2020. doi: 10.1016/j. fm.2014.08.009.

SENDRA, E. et al. Effect of Food Composition on Probiotic Bacteria Viability. In: WATSON, R. R.; PREEDY, V. R. Probiotics, Prebiotics, and Synbiotics: Bioactive Foods in Health Promotion. Amsterdam: Elsevier, 2016. Chap.17, p.257-269. Available from: <https://www.sciencedirect.com/ science/article/pii/B9780128021897000174?via\%3Dihub>. Accessed: Sep. 22, 2020. doi: 10.1016/B978-0-12-8021897.00017-4.

TAJCHAKAVIT, S. et al. Kinetics of haze formation and factors influencing the development of haze in clarified apple juice. Food Research International, v.34, p.431-440, 2001. Available from: <https://www.sciencedirect.com/science/article/abs/pii/ S0963996900001885?via\%3Dihub>. Accessed: Mar. 24, 2020. doi: 10.1016/S0963-9969(00)00188-5.

VIRK, A. et al. A Randomized, double blind, placebo-controlled trial of an oral synbiotic (AKSB) for prevention of travelers' diarrhea. Journal of Travel Medicine, v.20, p.88-94, 2013. Available from: $<$ https://www.ncbi.nlm.nih.gov/pubmed/23464715>. Accessed: Mar. 24, 2020. doi: $10.1111 /$ jtm. 12008.

WALKER, G. M. Metals in yeast fermentation processes. Advances in Applied Microbiology, p.197-229, 2004. Available from: <https://www.sciencedirect.com/science/ article/pii/S006521640454008X?via\%3Dihub>. Accessed: Jan. 17, 2020. doi: 10.1016/S0065-2164(04)54008-X.

WANG, J. et al. Fermentation characteristics and transit tolerance of probiotic Lactobacillus casei Zhang in soymilk and bovine milk during storage. Journal of Dairy Science, v.92, n.6, p.2468-2476, 2009. Available from: <https://www. sciencedirect.com/science/article/pii/S0022030209705612>. Accessed: Jun. 21, 2020. doi: 10.3168/jds.2008-1849. 
YANG, J. Brazil nuts and associated health benefits: A review. LWT - Food Science and Technology, v.42, p.1573-1580, 2009. Available from: <https:/www.sciencedirect.com/science/article/ pii/S0023643809001522?via\%3Dihub>. Accessed: Jan. 17, 2020. doi: 10.1016/j.lwt.2009.05.019.

ZENDEBOODI, F. et al. Probiotic: conceptualization from a new approach. Current Opinion in Food Science. v.32, p.103-123, 2020. Available from: <https://www.sciencedirect.com/science/
article/abs/pii/S221479932030028X>. Accessed: Jun. 18, 2020. doi: $10.1016 /$ j.cofs.2020.03.009.

ZHENG, X. et al. Comparing product stability of probiotic beverages using litchi juice treated by high hydrostatic pressure and heat as substrates. Innovative Food Science and Emerging Technologies, v.23, p.61-67, 2014. Available from: $<$ https://www. sciencedirect.com/science/article/abs/pii/S1466856414000253>. Accessed: Jun. 29, 2020. doi: 10.1016/j.ifset.2014.01.013. 